\title{
Detection of Bordetella avium by TaqMan real-time PCR in tracheal swabs from wildlife birds
}

\author{
T. Stenzel ${ }^{1}$, D. Pestka ${ }^{1}$, B. Tykałowski1 ${ }^{1}$, M. Śmiałek ${ }^{1}$, A. Koncicki ${ }^{1}$, \\ A. Bancerz-Kisiel ${ }^{2}$ \\ ${ }^{1}$ Department of Poultry Diseases, Faculty of Veterinary Medicine, \\ University of Warmia and Mazury, Oczapowskiego 13, 10-719 Olsztyn, Poland \\ ${ }^{2}$ Department of Epizootiology, Faculty of Veterinary Medicine, \\ University of Warmia and Mazury, Oczapowskiego 13, 10-719 Olsztyn, Poland
}

\begin{abstract}
Bordetella avium, the causing agent of bordetellosis, a highly contagious infection of the respiratory tract in young poultry, causes significant losses in poultry farming throughout the world. Wildlife birds can be a reservoir of various pathogens that infect farm animals. For this reason the studies were conducted to estimate the prevalence of Bordetella avium in wildlife birds in Poland. Tracheal swab samples were collected from 650 birds representing 27 species. The bacterial DNA was isolated directly from the swabs and screened for Bordetella avium by TaqMan real-time PCR.

The assay specificity was evaluated by testing DNA isolated from 8 other bacteria that can be present in avian respiratory tract, and there was no amplification from non-Bordetella avium agents. Test sensitivity was determined by preparing standard tenfold serial dilutions of DNA isolated from positive control. The assay revealed to be sensitive, with detection limit of approximately $4.07 \times 10^{\wedge} 2$ copies of Bordetella avium DNA. The genetic material of Bordetella avium was found in $54.54 \%$ of common pheasants, in $9.09 \%$ of Eurasian coots, in $3.22 \%$ of black-headed gulls and in $2.77 \%$ of mallard ducks.

The results of this study point to low prevalence of Bordetella avium infections in wildlife birds. The results also show that described molecular assay proved to be suitable for the rapid diagnosis of bordetellosis in the routine diagnostic laboratory.
\end{abstract}

Key words: Bordetella avium, TaqMan real-time PCR, wildlife birds 


\section{Introduction}

Bordetella avium (B. avium), a Gram-negative, non-fermentative, strictly aerobic, motile bacterium from the genus Bordetella causes bordetellosis, a highly contagious infection of the respiratory tract in young poultry, which is characterized by high morbidity (up to $100 \%$ birds in the flock) and relatively low mortality (Jackwood et al. 1995). Bordetella avium is also associated with the Lockjaw Syndrome in psittacine birds (Grespan et al. 2012). Bordetellosis causes significant losses in poultry farming throughout the world, mainly by predisposing birds to secondary infections. This disease affects mainly young turkeys, whereas in chickens, only several strains are able to induce clinical disease. Bordetellosis usually has a milder course in chickens than in turkey poults (Rimler 1985, Jackwood et al. 1995).

Four toxins produced by Bordetella avium: endotoxin, tracheal cytotoxin, heat-labile dermonecrotic toxin and osteotoxin, were isolated to analyze the pathogenesis of B. avium infections (Rimler 1985). The above substances have been researched extensively, but their role in the pathogenesis of bordetellosis has not been fully explained. Deformation of tracheal rings and damage to articular cartilages, which are observed in some field cases of B. avium infections, could be associated with osteotoxin activity (Yersin et al. 1991).

Bordetella avium has to adhere to tracheal epithelial cells to colonize the respiratory tract of turkeys (Arp et al. 1988, Temple et al. 2010). Hemagglutinin produced by $B$. avium as well as autotransporter proteins and fimbriae play the main role in this process (Arp et al. 1988, Hellwig et al. 1988, Moore and Jackwood 1994, Loker et al. 2011, Stockwell et al. 2011). Interestingly, the fimbrial locus of B. avium is regulated in response to temperature $\left(37^{\circ} \mathrm{C}\right)$, and the bacterium is able to adhere to the host's respiratory epithelium only under such conditions (Loker et al. 2011).

Wildlife birds can be a reservoir of various pathogens that infect farm animals and humans (Stenzel et al. 2008, Benskin et al. 2009, Bancerz-Kisiel et al. 2012). Despite the above, very little is known about the incidence of Bordetella avium in populations of wildlife birds. A US study revealed that Bordetella avium can affect mallards, Canada geese, wild turkeys and birds kept in Zoos (Hopkins et al. 1990, Raffel et al. 2002, Hollamby et al. 2003).

The golden standard in diagnosis of bacterial infections is bacterial culture. In the literature there are reports about molecular diagnosis of bacterial infections including Bordetella sp. (Register et al. 2005, Koidl et al. 2007). The described methods requires multiplication of bacteria before the DNA extraction, so if the sample contains bacteria, it should be alive. Live bacteria is not required for successful DNA extraction for molecular methods, which is the main advantage of this diagnostic procedure. The quantity of bacterial genetic material in field samples usually is low, therefore a very sensitive diagnostic method is required for obtaining the reliable results. In the light of the above the main aim of this study was to develop a sensitive method for molecular diagnosis of Bordetella avium directly from avian tracheal swabs. Having regard to the fact that wildlife birds can be a reservoir and vector of $B$. avium for poultry, the second aim of this investigation was to estimate the prevalence of $B$. avium in wildlife birds in Poland.

\section{Materials and Methods}

Experimental material was collected in 2010-2014 from wildlife birds that were harvested by hunters or caught by ornithologists during ringing actions. In 2010, waterfowl kept in a free-range aviary in the Gdańsk Zoo (Poland) were also tested. Tracheal swab samples were collected from birds with the use of the commercial transport system (ESwab Collection and Transport System, Copan Diagnostic, USA). A total of 650 birds representing 27 species were analyzed. The list of examined birds is presented in Table 1.

The bacterial DNA was extracted directly from the swab transport medium, without prior culture of bacteria. Before attempting to isolate DNA from the swabs, the entire swab transport medium was transferred to a microtube and centrifuged (5430 $\mathrm{R}$ centrifuge, Eppendorf, Germany) at 240xg for 15 minutes at $4^{\circ} \mathrm{C}$. The supernatant was discarded and the cellular pellet was suspended in $170 \mu \mathrm{L}$ phosphate buffered saline solution (PBS). DNA was extracted by the magnetic method using the automated workstation (Janus, Perkin Elmer, USA) and the commercial kit (NucleoMag Tissue Kit, Macherey-Nagel, Germany) in accordance with the manufacturer's instructions. The concentrations of eluted DNA were measured using the spectrophotometer (NanoDrop 2000, Thermo Scientific, USA) and DNA was stored at $-80^{\circ} \mathrm{C}$ for further analysis.

Screening for Bordetella avium was performed by TaqMan real-time PCR. The reaction was carried out with the use of the commercial kit (TaqMan Fast Universal PCR MasterMix, Life Technologies, USA) and the following primers: BArecAFwd 5'-CGGTTCGCTGGGCTTGG-3', BArecARev 5'-CACGCGGCAGCCCGC-3' and BarecA Hex CATCGCGCTGGGTG BHQ-1 probe amplifying 
Table 1. List of samples collected in 2010-2014 and the results of TaqMan real-time PCR screening for the presence of Bordetella avium genetic material in tracheal swab from wildlife birds.

\begin{tabular}{|c|c|c|c|c|c|}
\hline \multirow{2}{*}{ Scientific name } & \multirow{2}{*}{ Common name } & \multicolumn{2}{|c|}{ Number of samples } & \multicolumn{2}{|c|}{$\begin{array}{l}\text { Number of samples } \\
\text { positive for B. avium }\end{array}$} \\
\hline & & $\mathrm{n}$ & $\%$ & $\mathrm{n}$ & $\%$ \\
\hline Alca torda & Razorbill & 1 & 0.15 & 0 & 0 \\
\hline Anas crecca & Euroasian teal & 14 & 2.15 & 0 & 0 \\
\hline Anas platyrhynchos & Mallard duck & 397 & 61.1 & 11 & 2.77 \\
\hline Anser anser & Greylag goose & 3 & 0.46 & 0 & 0 \\
\hline Anser albifrons & White frontem goose & 2 & 0.31 & 0 & 0 \\
\hline Anser fabalis & Bean goose & 8 & 1.23 & 0 & 0 \\
\hline Aquila pomarina & Lesser spotted eagle & 1 & 0.15 & 0 & 0 \\
\hline Aythya fuligula & Tufted duck & 3 & 0.46 & 0 & 0 \\
\hline Buteo buteo & Common buzzard & 1 & 0.15 & 0 & 0 \\
\hline Chroicocephalus ridibundus & Black-headed gull & 31 & 4.77 & 1 & 3.22 \\
\hline Clangula hyemalis & Long-tailed duck & 1 & 0.15 & 0 & 0 \\
\hline Corvus corone cornix & Hooded crow & 3 & 0.46 & 0 & 0 \\
\hline Corvus monedula & Jackdaw & 1 & 0.15 & 0 & 0 \\
\hline Cygnus olor & Mute swan & 43 & 6.62 & 0 & 0 \\
\hline Fulica atra & Euroasian coot & 11 & 1.7 & 1 & 9.09 \\
\hline Gavia stel lata & Red-throated loon & 1 & 0.15 & 0 & 0 \\
\hline Haliaeetus albicilla & White-tailed eagle & 1 & 0.15 & 0 & 0 \\
\hline Larus argentatus & Herring gull & 15 & 2.31 & 0 & 0 \\
\hline Larus canus & Common gull & 4 & 0.61 & 0 & 0 \\
\hline Melanita fusca & Velvet scoter & 4 & 0.61 & 0 & 0 \\
\hline Pelecanus onocrotalus & Great white pelican & 13 & 2 & 0 & 0 \\
\hline Pernis apivorus & Honey buzzard & 1 & 0.15 & 0 & 0 \\
\hline Phalacrocorax carbo & Black cormorant & 49 & 7.54 & 0 & 0 \\
\hline Phasianus colchicus & Common pheasant & 22 & 3.39 & 12 & 54.54 \\
\hline Phoenicopterus ruber & American flamingo & 16 & 2.47 & 0 & 0 \\
\hline Pica pica & Euroasian magpie & 3 & 0.46 & 0 & 0 \\
\hline \multirow[t]{2}{*}{ Podiceps cristatus } & Great crested grebe & 1 & 0.15 & 0 & 0 \\
\hline & & 650 & 100 & & \\
\hline
\end{tabular}

a $\sim 50$ bp region of the $B$. avium $\operatorname{Rec} A$ gene (GenBank accession no. AY124330).

The reaction was performed in the thermocycler (MX 3005P, Stratagene /Agilent technologies, USA) at the final volume of $20 \mu \mathrm{L}$, comprising $10 \mu \mathrm{L}$ of the TaqMan Fast Universal PCR MasterMix, $1.8 \mu \mathrm{L}$ of each primer $(10 \mu \mathrm{M}), 2 \mu \mathrm{L}$ of the labeled probe $(2.5$ $\mu \mathrm{M})$ and $4.4 \mu \mathrm{L}$ of purified DNA. The following thermal cycling parameters were applied: $95^{\circ} \mathrm{C}$ for $30 \mathrm{~s}, 40$ cycles of a two-stage temperature profile of $95^{\circ} \mathrm{C}$ for $15 \mathrm{~s}$ and $60^{\circ} \mathrm{C}$ for $1 \mathrm{~min}$.

Test specificity was evaluated by testing DNA isolated from other pathogens that can be present in avian respiratory tract: Pasteurella multocida (ATCC 12945), Ornithobacterium rhinotracheale (ATCC 51463), Klebsiella pneumoniae (ATCC 13882), Escherichia coli (ATCC 10536), Mycoplasma (M.) gallisepticum (ATCC 19610), Mycoplasma iowae (ATCC 33552), Mycoplasma synoviae (ATCC 25204) and Mycoplasma meleagridis (ATCC 25294).

Assay sensitivity was determined by preparing the standard curve. The first step of this procedure was amplification of a $740 \mathrm{bp}$ fragment of $\mathrm{Ba} \operatorname{Rec} \mathrm{A}$ gene. The amplified fragment contained a sequences complementary for BArecA primers and probe. The reaction was carried out in a thermocycler (Mastercycler, Eppendorf, Germany) using the commercial reagent kit (HotStarTaq Plus Master Mix Kit, Qiagen, Netherlands) and a pair of primers: B.aviumrecA740bpF 3'-CCGCTTATGCATGACCGTTT-5' and B.aviumrecA740bpR 3'-TTCAGGGTTGCCGAACATCA-5'. The contents of the reaction mixture were as follows: $10 \mu \mathrm{L}$ of HotStarTaq Plus Master Mix, $0.1 \mu \mathrm{L}$ of each primer $(100 \mu \mathrm{M}), 2 \mu \mathrm{L}$ of loading dye ${ }^{\mathrm{i}}, 2 \mu \mathrm{L}$ of template DNA and $5.82 \mu \mathrm{L}$ of water. The PCR conditions were as follows: $95^{\circ} \mathrm{C}$ for 5 minutes; then 30 cycles: $94^{\circ} \mathrm{C}$ for $60 \mathrm{~s}, 60^{\circ} \mathrm{C}$ for $60 \mathrm{~s}$ and $72^{\circ} \mathrm{C}$ for $90 \mathrm{~s}$; final elongation after the last cycle at $72^{\circ} \mathrm{C}$ for 10 minutes. The resulting product was purified from the residues of buffer and nucleotides using commercial kit (Clean-Up, A\&A Biotechnology, Poland) and next the concentration of amplicon was measured using a spectrophotometer (NanoDrop 2000, Thermo Scientific, USA). Afterwards, the gene copy number 


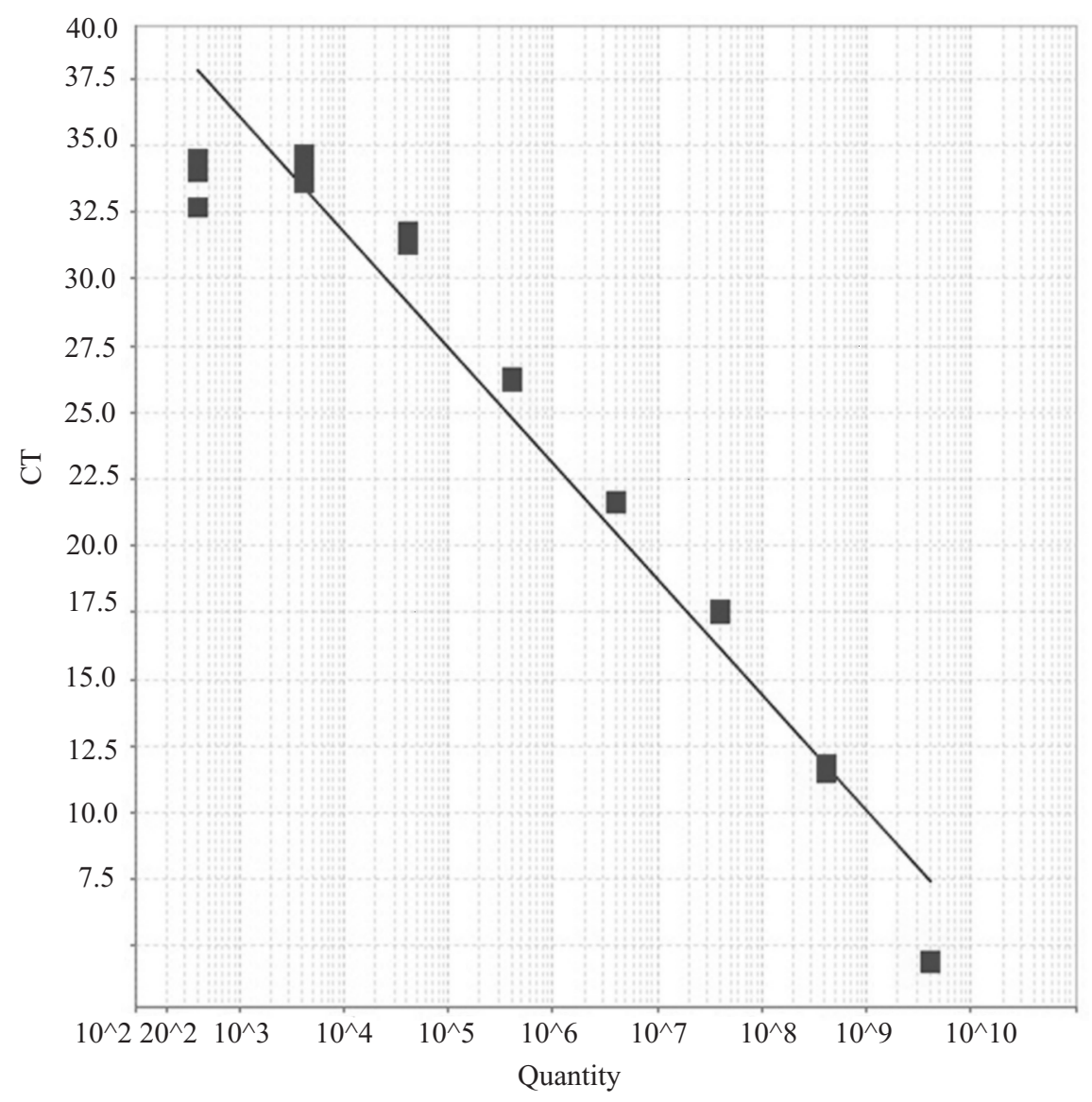

Fig. 1. The standard curve derived from tenfold serial dilutions of DNA isolated from positive control (Bordetella avium, ATCC 35086).

resulting from the concentration and size of the amplicon was calculated using ds DNA calculator software (dsDNA copy number calculator, Rhode Island Genomic and Sequencing Center, USA).

The next step was to prepare standard tenfold serial dilutions of amplicon used as a template DNA. Aliquots of each dilution (initial dilution: $10^{\wedge} 10$, final dilution: 10^2) were subjected to the TaqMan real-time PCR assay to determine the lowest number of DNA copies that can be detected with the assay.

During examination of field samples the fluorescence curves were analyzed with thermocycler software. The results were expressed by determination of the threshold of detection, or crossing point $(\mathrm{Cp})$, which marked the cycle at which fluorescence of the sample became significantly different from the baseline signal. Each DNA sample was submitted to TaqMan real-time PCR amplification in duplicate. The samples were recognized as positive when the $\mathrm{Cp}$ value was lower than 35 cycles in both replicates. One positive control and two negative controls were added to each run. Positive control consisted of DNA isolated directly from a laboratory culture of Bordetella avium (ATCC 35086), whereas negative controls were two sterile water samples, one submitted to the extraction and amplification protocols and the other submitted only to the amplification protocol. This was done to verify that there was no contamination in any step of the technical procedure.

\section{Results}

The assay revealed to be highly sensitive and specific. Test specificity has shown that there was no amplification from non- $B$. avium agents sequences. The detection limit in sensitivity evaluation was $4.07 \times 10^{\wedge} 2$ copies of Bordetella avium DNA. The standard curve was linear over a wide range of dilutions (Slope: -4.33; R2: 0.953; Efficiency: 70.1\%) (Fig. 1).

Samples positive for Bordetella avium are characterized in Table 1. A total of 25 birds (3.84\%) of the examined population, tested positive for $B$. avium. The genetic material of $B$. avium was found in 12 out of 22 examined common pheasants (54.54\%), in 1 out of 11 Eurasian coots $(9.09 \%)$, in 1 out of 31 black-headed gulls (3.22\%) and in 11 out of 397 mallard ducks $(2.77 \%)$. None of the examined Zoo birds tested positive for Bordetella avium. 


\section{Discussion}

A rapid and reliable diagnostic method is essential for the correct treatment of each infectious disease. For many years culture has been considered as a gold standard for the detection of several bacteria, but this method often lacks sensitivity and also requires a few days of examination. The molecular methods have been reported to be more sensitive and specific than traditional diagnosis of bacterial infections (Dragsted et al. 2004).

In our study, a new molecular method for the detection of Bordetella avium based on automated DNA extraction and TaqMan real-time PCR was evaluated. The results have shown that assay is specific and sensitive with detection limit of approximately $4.07 \times 10^{2}$ copies of Bordetella avium DNA.

A US study on the prevalence of Bordetella avium in wildlife birds revealed that the bacterium can colonize large range of avian species (Hopkins et al. 1990, Raffel et al. 2002). The antibodies against this bacterium were detected in $45 \%$ of the serum samples collected from 62 species of wildlife birds. The seroprevalence was the highest in waterfowl birds like great blue herons (Ardea herodias), canada geese (Branta canadiensis), muscovy ducks (Carina moschata), mallards (Anas platyrhynchos) and birds belonging to the order Passeriformes: blue jays (Cyanocitta cristata) and american crows (Corvus brachyrhynchos). The antibodies against $B$. avium were also found in Galliformes birds like ring necked pheasants (Phasianus colchicus) and wild turkeys (Meleagris gallopavo) (Raffel et al. 2002). Bordetella avium was also isolated from wildlife birds in Europe. Szabó et al. (2015) performed antimicrobial susceptibility tests of $B$. avium strains isolated from wildlife waterfowl (geese and ducks of unknown species) and partridge (Perdix perdix).

Turkeys (Meleagris gallopavo) are the typical hosts for $B$. avium, but this species is not encountered in the wild in Poland. In our study, Bordetella avium was most prevalent in the common pheasant, also a member of the order Galliformes. All pheasants that tested positive for B. avium were harvested by hunters in the same hunting district where pheasants are released into the wild by the same commercial aviary every year. All hunted birds originated from the same, infected, but probably asymptomatic flock. We were unable to obtain samples from that flock, therefore, our hypothesis remains unverified.

The presence of Bordetella avium genetic material in tracheal swabs from wild waterfowl indicates that those birds could be a $B$. avium carriers. Infections spread easily among aquatic birds during migration when birds congregate in large flocks. Migratory birds often stop over for short periods of time in the same, often very shallow bodies of water, which contributes to the transmission of pathogens not only between individuals of the same species, but also between different species of birds. The above could explain the presence of Bordetella avium genetic material in mallard ducks, as well as in Eurasian coots and black-headed gulls. The above results partially correspond with investigation of Raffel et al. (2002) who found that isolation rate of $B$. avium from tracheas of wildlife birds is quite low. Those authors have found this bacterium only in 9/128 tracheal swab samples collected from 24 avian species (7 obtained from mallards and one from canada goose and wild turkey, respectively).

The results of this study indicate that the used method is a quick, convenient and not requiring a bacterial culture, way for diagnosis $B$. avium from clinical samples of birds. This assay can be a sensitive, specific and fast alternative method in the routine diagnostic laboratory. Rapid laboratory diagnosis of turkey coryza can be a useful tool for practicing veterinarians, because the prevalence of Bordelella avium in domesticated turkeys bred in Poland is very high (44 - $100 \%$ of flocks depending on the age) which was confirmed by serological screening (Śmiałek et al. 2015). The obtained results also point to low prevalence of Bordetella avium infections in wildlife birds. However, wild birds can be a reservoir of this bacterium and they can pose a threat for domestic poultry, in particular when biosecurity requirements are not restricted.

\section{Acknowledgements}

This research study was funded by grant NR-12-0126-10.

\section{References}

Arp LH, Leyh RD, Griffith RW (1988) Adherence of Bordetella avium to tracheal mucosa of turkeys: correlation with hemagglutination. Am J Vet Res 49: 693-696.

Bancerz-Kisiel A, Szczerba-Turek A, Lipczyńska K, Stenzel $\mathrm{T}$, Szweda W (2012) Bioserotypes and virulence markers of Yersinia enterocolitica strains isolated from mallards (Anas platyrhynchos) and pheasants (Phasianus colchicus). J Food Prot 75: 2219-2222.

Benskin C M H, Wilson K, Jones K, Hartley IR (2009) Bacterial pathogens in wild birds: a review of the frequency and effects of infection. Biol Rev Camb Philos Soc 84: 349-373.

Dragsted DM, Dohn B, Madsen J, Jensen JS (2004) Comparison of culture and PCR for detection of Bordetella pertussis and Bordetella parapertussis under routine laboratory conditions. J Med Microbiol 53: 749-754. 
Grespan A, Camera O, Knobl T, Gomes CR, Felizardo MR, Ferreira TS, Gobbi DD, Moreno M, Sanches AA, Ferreira CS, Ferreira AJ, Moreno AM (2012) Virulence and molecular aspects of Bordetella avium isolated from cockatiel chicks (Nymphicus hollandicus) in Brazil. Vet Microbiol 160: 530-534.

Hellwig DH, Arp LH, Fagerland JA (1988) A comparison of outer membrane proteins and surface characteristics of adhesive and non-adhesive phenotypes of Bordetella avium. Avian Dis 32: 787-792.

Hollamby S, Sikarskie JG, Stuht J (2003) Survey of peafowl (Pavo cristatus) for potential pathogens at three Michigan zoos. J Zoo Wildl Med 34: 375-379.

Hopkins BA, Skeeles JK, Houghten GE, Slage D, Gardner K (1990) A survey of infectious diseases in wild turkeys (Meleagridis gallopavo silvestris) from Arkansas. J Wildl Dis 26: 468-472.

Jackwood MW, McCarter SM, Brown TP (1995) Bordetella avium: an opportunistic pathogen in Leghorn chickens. Avian Dis 39: 360-367.

Koidl C, Bozic M, Burmeister A, Hess M, Marth E, Kessler HH (2007) Detection and differentiation of Bordetella spp. by real-time PCR. J Clin Microbiol 45: 347-350.

Moore KM, Jackwood MW (1994) Production of monoclonal antibodies to the Bordetella avium 41-kilodalton surface protein and characterization of the hemagglutinin. Avian Dis 38: 218-224.

Loker SB, Temple LM, Preston A (2011) The Bordetella avium BAV1965-1962 fimbrial locus is regulated by temperature and produces fimbriae involved in adherence to turkey tracheal tissue. Infect Immun 79: 2423-2429.
Raffel TR, Register KB, Marks SA, Temple L (2002) Prevalence of Bordetella avium infection in selected wild and domesticated birds in the eastern USA. J Wildl Dis 38: 40-46.

Register KB, Yersin AG (2005) Analytical verification of a PCR assay for identification of Bordetella avium. J Clin Microbiol 43: 5567-5573.

Rimler RB (1985) Turkey coryza: toxin production by Bordetella avium. Avian Dis 29: 1043-1047.

Stenzel T, Tykałowski B, Mazur-Lech B, Koncicki A (2008) Infections in wildlife birds - results of serological screening. Bull Vet Inst Pulawy 52: 63-66.

Stockwell SB, Kuzmiak-Ngiam H, Beach NM, Miyamoto D, Fernandez R, Temple L (2011) The autotransporter protein from Bordetella avium, Baa1, is involved in host cell attachment. Microbiol Res 167: 55-60.

Szabó R, Wehmann E, Magyar T (2015) Antimicrobial susceptibility of Bordetella avium and Ornithobacterium rhinotracheale strains from wild and domesticated birds in Hungary. Acta Vet Hung 63: 413-424.

Śmiałek M, Tykałowski B, Pestka D, Stenzel T, Koncicki A (2015) Epidemiological situation of turkey coryza (bordetellosis) in Poland. Pol J Vet Sci 18: 659-661.

Temple LM, Miyamoto DM, Mehta M, Capitini CM, Von Stetina S, Barnes HJ, Christensen VL, Horton JR, Spears PA, Orndorff PE (2010) Identification and characterization of two Bordetella avium gene products required for hemagglutination. Infect Immun 78: 2370-2376.

Yersin AG, Edens FW, Simmons DG (1991) Effect of Bordetella avium infection on electrocardiograms in turkey poults. Avian Dis 35: 668-673. 